\title{
The Role of Festivals in Awo-Omamma-Amiri Relations, since
} 1970

\author{
Kelechi Chika Ubaku ${ }^{1}$ \\ ${ }^{l}$ Department of History and International Studies, Nnamdi Azikiwe University, Awka, Anambra State, Nigeria
}

\begin{abstract}
This paper examines the roles of the Owu, Okorosha, and new yam festivals in the post NigerianBiafran Civil War relations of Awo-Omamma and Amiri towns. To ensure ample comprehension of the study, the information contained in the paper were provided under different sub-headings and according to their demands. Historical methodology of data gathering was adopted in the study where a wide range of sources, to include primary and secondary sources, were utilized. Finally, the paper concludes that despite the recent Otunne political conundrum, the Owu, Okorosha, and new yam festivals have continued to provide the pedestal for friendliness between the indigenes of the aforementioned towns, through cordial social and cultural relations.
\end{abstract}

Keywords: Awo-Omamma, Amiri, Owu, Okorosha, New Yam.

\section{Introduction}

Nigeria, an African political entity with the colonial seal of made in Britain, was not born until 1914, following the British colonial policy of amalgamation which saw the unification of diverse ethnic nationalities into an artificial political entity. It has borders with the Republic of Benin in the west, Niger and Chad Republics in the north, and the Republic of Cameroon in the east [1]. As the world's most populous black nation, the political entity has a population of 166.2 million people (as recorded in 2012 by the Nigerian National Bureau of Statistics) [2], and covers a geographical area of 923, 768 square kilometres [3].

The amalgamation of 1914 made Nigeria a heterogeneous geo-polity accommodating over two hundred and fifty (250) ethnic nationalities, which are grouped under the majorities' and the minorities' categories. While the majorities include the Igbo, the Hausa/Fulani, and the Yoruba, some of the minorities therefore include the Tiv of Benue State, the Itshekiri of Delta State, the Ibibio of Akwa Ibom State, the Efik of Cross River State, the Ijaw of Rivers State, the Akoko of Edo State, and the Igbirra of Kogi State, etcetera. These ethnic nationalities have different cultural identities which do not only say lots about them but also distinguish them from others. These cultural identities are mostly found in their cultural festivals.

As one of the Nigerian ethnic nationalities, thus, the Igbo people have different cultural festivals which say much about their heritage and ancestry. The people of Awo-Omamma, and Amiri towns in Oru East Local Government Area of Imo State, for instance, are known with the Owu, Okorosha, and the new yam festivals, which have also been playing prominent roles in their post-Nigerian/Biafran Civil War relations. These roles thus are the focus of the study.

\section{A Description of Awo-Omamma, and Amiri}

Awo-Omamma, and Amiri are neighbouring towns situated in the present day Oru East Local Government Area of Imo State. Awo-Omamma is dichotomized into Ofekata and Eziawo sections, and it covers an area of about 89.2 square kilometres [4]. The town is bounded in the north by Mgbidi and Otulu towns in Oru West Local Government Area, as well as Amiri town in Oru East Local Government Area; in the east by Okwudor town in Njaba Local Government Area; in the west by Oguta Local Government Area; and in the south by Eziama-Obiato town in Mbaitolu Local Government Area. The famous Njaba River which rises from Isu-Njaba in Njaba Local Government Area of Imo State washes the southern part of Awo-Omamma.

As a neighbouring town, on the other hand, Amiri is bounded in the north by Omuma town in Oru East Local Government Area; in the south by Awo-Omamma in Oru East Local Government Area; in the east by Atta, and Okwudor towns in Njaba Local Government Area; and in the west by Otulu in Oru West Local Government Area.

Both towns lie on the Owerri-Onitsha trunk 'A' road, and possess topographies of level fertile lands with low plains. The presence of the Njaba River provides the indigenes of both towns with access to natural water supply.

Presently, Awo-Omamma, and Amiri consist of ten autonomous communities. Six of these autonomous communities are found in Awo-Omamma, while four are found in Amiri. Kelechi C. Ubaku provided the names 
of some of these autonomous communities and their traditional rulers. According to him, the autonomous communities in Awo-Omamma with their traditional rulers include Ofekata I, HRH Eze Anthony Nnabuo (Ezeudo III of Ofekata I); Ofekata II, HRH Eze Benard Amanfo (Ezeoha IV of Ofekata II); Ofekata III, HRH Eze Polycarp Abanukam (Okosisi I of Ofekata III); Ofekata IV (also known as Umueme-Umezeali autonomous community), HRH Eze Titus Ngimah (Uchekaku I); Eziawo I, HRH Eze Leonard Amukamara (Egbuador III of Eziawo I); and Eziawo II, HRH Eze Theophilus Onyenekwu (Imo IV of Eziawo II). On the other hand, Amiri town possesses the following autonomous communities and their traditional rulers: Amiri Isu, HRH Eze B.N. Igbojekwe (Gedegwum I of Amiri Isu); Amiri Oru, HRH Eze D.D. Nnabuo (Igwe III of Amiri Oru); and Umuduruigwemmadu, HRH Eze N.N. Obilom (Duruoha IV of Umuduruigwemmadu) [5]. Mbubu Amiri autonomous community ruled by HRH Eze Cyril Uzoukwu (Mbu I of Mbubu Amiri) did not appear in his study as one of the autonomous communities found in Amiri town. This is because, the period of his research predates the period when Mbubu Amiri was officially recognized as an autonomous community. However, "the official recognition of Mbubu Amiri as an autonomous community in April 2012, by the government of Imo State, brought the numbers of autonomous communities in Amiri town to four" [6].

Additionally, there are twenty-three villages in Awo-Omamma, and Amiri, which are components of the autonomous communities found in the aforementioned towns. While thirteen of these villages are found in $A w o-$ Omamma, ten are found in Amiri. The villages in Awo-Omamma include Ubogwu in Ofekata I autonomous community; Ubachima in Ofekata II autonomous community; Okworji, and Umubochi in Ofekata III autonomous community; Umuezeali, and Umueme in Ofekata IV autonomous community; Umuokwe, Obibi, and Ohuba in Eziawo I autonomous community; and Isieke, Umuezukwe, Ubahaeze, and Umuezike in Eziawo II autonomous community. Umuelibe is not recognised as one of the villages in Awo-Omamma. This is because, "its recent self-acclaimed autonomy (as a village) from Okworji is yet to be recognized" [7]. On the other hand, Amiri town has the following as villages: Ubahazu, Nchoko, and Ugbeke in Amiri Oru autonomous community; Umuocheta, Amuka, Isiorie, and Umudioka in Amiri Isu autonomous community; Umuduru in Umuduruigwemmadu autonomous community; and Amaokpara, and Mbubu (which were formerly in Amiri Oru autonomous community) in Mbubu Amiri autonomous community. Under these villages are sixty-seven kindredthirty-six in Awo-Omamma, and thirty-one in Amiri [8].

The indigenes of Awo-Omamma and Amiri have various occupations. Consequently, there exist artisans, bicycle repairers, bricklayers, and agriculturalists, etc. In addition, there are traders who transact variety of businesses in the markets of these towns, and some of these markets include Afor market in Isieke, Eke market in Okworji, Eke Achara market in Ubogwu, and Nkwo market in Umuokwe villages (all in Awo-Omamma); and Orie Amiri market, Afor market in Ubahazu, Nkwo market in Nchoko, and Eke market in Umuocheta villages (all in Amiri). The market squares of some of these markets, as noted by Kelechi C. Ubaku "...serve as centres for the exhibition of masquerades and dances in Awo-Omamma, and Amiri towns" [9].

Religiously, there is a strong belief in the famous deity - the Njaba Deity- existing among the indigenes of these towns. The deity, as pointed out by Hyginus Ojinnaka "exists as male and female folks inhabiting in the famous Njaba River" [10]. Due to its reverence in both towns, the Eke Njaba (a harmless traditional snake regarded as the property of the deity) is held sacred- a traditional practice which is synonymous to that carried out in the towns of Idemili, Anambra State, in favour of Eke Idemili [11]. This belief is so strong that even the Christians have not completely renounced the sacredness of the Eke Njaba which can neither be killed nor harmed. Killing the sacred snake deliberately or accidentally will require a ritual cleansing by the culprit else, his or her family members will experience the wrath of the Njaba Deity. However, with the current inexistence of the Ibini Ukpabi (Aro long juju)- a deity which had existed in Arochukwu town of Abia State, Arusi Okija- a strong deity which had existed in Okija town of Anambra State, and Ala Ogbaga- equally a strong deity which had existed in Mbaise town of Imo State, it could be incontestable to assert that currently, the Njaba Deity is the strongest deity not just in eastern Nigeria, but in the country, Nigeria.

\section{Festival as a concept}

Festivals are exclusively human activities which are celebrated communally. They involve meticulously planned programs, rejoicing, outpouring of respects or high revelry, established by custom or sponsored by various organizations or groups. As a term, Festival has been defined by different sources. For instance, while D. Getz saw the term as the celebration of "...town values, ideologies, identity and continuity" [12], another source however defined it as

A day or period set aside for celebration or feasting, esp (especially) one of religious significance; any occasion for celebration, esp one which commemorates an anniversary or other significant event; an organized series of special events and performances, usually in one place...; ...time of revelry... [13]. 
G.T. Basden, in his words, sees festival as “...nothing more than a fete with dancing, music, feasting and general manifestations of pleasure and enjoyment, with congratulations for the year past and good wishes for the year ahead" [14]. On the significance of music, dance, and song to the town during festival, he thus maintained that they "... are instruments for creating social, emotional, and aesthetic solidarity" [15]. On the other hand, A. Falassi defined festival as "a sacred or profane time of celebration, marked by special observances" [16], while D. Getz equally saw the term as "themed public celebration" [17]. J. Pieper in his view, however, remarked that festivals involve only religious rituals and celebrations [18].

In Igbo land, festivals possess different areas of significance. In Awo-Omamma, and Amiri towns, for instance, festivals, in the post Nigerian-Biafran Civil War era, have been acting as catalysts for social and cultural cooperation among the indigenes of the aforementioned towns. Some of them thus include the Owu festival, the Okorosha festival, and the New Yam festival.

\section{Owu Festival in Awo-Omamma-Amiri Relations}

The $O w u$ (also called $O g h u$ ) festival is an annually celebrated cultural dance festival in Awo-Omamma, and Amiri towns. Though known as an Oru (a region in Imo West Senatorial District which is made up of towns believed to possess a common descent, where Awo-Omamma and Amiri towns are located) festival, the Owu festival is equally celebrated annually by non-Oru towns neighbouring the aforementioned towns. Vin Okeke concurs to this when he asserted that the $O w u$ festival

.... is an Oru based festival celebrated by Mgbidi,...Omuma, Otulu, and in the Oguta clan- Izombe, Awa, Nkweshi, Mgbele, Oboroti; it is celebrated also in Mbaitolu clan- Umunnoha, Ogbaku, Orodo; in Njaba clan- Umuaka, Okwudor. In fact, it is an Oru endowment though some towns which are not Oru in origin celebrate it out of influence and borrowed as well as learnt the tenets of it by interest and copying [19].

In Awo-Omamma and Amiri, however, the festival is usually celebrated in June every year within the Owu festive period - the period of the celebration of traditional festivals which usually stretches from mid-May to mid-August.

The origin of the festival is neither traceable to Awo-Omamma and Amiri towns nor the aforementioned neighbouring towns. The origin has to an extent remained controversial among writers. For instance, while T.C. Ngimah and Kelechi C. Ubaku concurred to the fact that the $O w u$ cultural festival originated from a riverine town known as Ogwu-Akiri [20], JohnCliff Nwadike and Joseph O. Nwoke posited that the origin of the cultural festival is traceable to "a village called Nkwesi... in Oguta L.G.A" [21], also recognized by T.C. Ngimah as a riverine area [22]. Be that as it may, the aforementioned sources in their various accounts on the origin of the festival concurred to the fact that the $O w u$ festival is not originally owned by Awo-Ommama, and Amiri people. However, its origin from the riverine area (as stated above) brought about the belief that the $O w u$ culture was a marine world's phenomenon which due to geographical proximity, diffused into the riverine towns. From there, it came into Awo-Omamma (from where it diffused into Amiri) through a certain slave from Okworji village.

The $O w u$ cultural dance in Awo-Omamma constitutes of three types of dances. They include the $O w u$ Abuba, Owu Oma, and Owu-Ulo-Akwa dances. Owu Abuba usually features every year during the celebration of the $O w u$ festival. In this variety of dance, the ceremonial dancers and the amateur members of the $O w u$ Cult participate freely without any objection. The $O w u$ Cult is an institution which coordinates the cultural festival. Its functionaries hierarchically (from the highest to the lowest) include the Osere- an $O w u$ terminology meaning Onye Isi Owu (the head of the Owu Cult); Ugbo- the second in hierarchy of the Owu Cult functionaries; Akpu/Iche- the third in command of the cult; and $A d a O w u$ - the fourth in the hierarchical ladder of the cult [23]. These four functionaries have the responsibilities of providing the ceremonial dancers who take part in the festival. These dancers are known as Nwaezeowu, which is usually provided by the Osere; Nwankpa, provided by the Ugbo; and two Owu Oma, each provided by Akpu/Iche and Ada Owu [24]. However, the celebration of this dance in Awo-Omamma promotes cultural cooperation and interaction between her indigenes and those of Amiri, as villages from both towns occasionally unite to celebrate the dance. This act of cooperation is usually common between the people of Isieke village in Awo-Omamma, and Umuocheta village in Amiri. This cooperation is usually encouraged with the belief of a blood relationship existing between the indigenes of these villages [25]. Genealogically, it is believed that majority of the people of Isieke village migrated from Umuocheta village and settled in their present location.

Apart from cooperation between villages, the celebration of the dance in a particular village in AwoOmamma (as the celebration of the $O w u$ festival is regulated according to villages) usually attracts members of both towns to the celebrating village. In most cases, marriage contacts are made by the indigenes of both towns as a result of their visits to the celebrating village.

Unlike the Owu Abuba, Owu Oma features periodically at the volition of the heads of the Owu Cult. The costumes for its celebration differ from that of Owu Abuba. For instance, while white singlet, white shorts, 
waist bands with assorted colour ribbons, and head dress adorned with fresh white feathers constitute the costumes for Owu Abuba, Owu Oma costumes include feathers, cloths, a tome designed and carried at the back embellished with multiple colours, and the head dress called agalaga which is an elongated structure decked with bright plumes at intervals. This variety of $O w u$ dance does not encourage the participation of amateur members of the $O w u$ Cult. In other words, only the ceremonial dancers provided by the functionaries of the cult participate in the dance. These ceremonial dancers thus include Nwaezeowu, Owuoma, and the scary father of masquerades known as Agwu, provided by the Osere; Nwankpa, and Owu Oma, provided by the Ugbo; Anyanwu (with a feature symbolizing the beauty of the sun), and one Owu Oma, provided by Akpu/Iche; and Olokoloja (also called Ebule Nwaolokoroja- a dancer with the feature of a masquerade who plays a comic role via his style of dance which runs counter to the beats provided by the drummers), and one Owu Oma, provided by the Ada $O w u$. Similar to $O w u A b u b a$, the celebration of this dance equally encourages cultural cooperation between $A w o-$ Omamma, and Amiri, as it attracts members of both towns to the celebrating village. In most cases, Owu dancers (equally ceremonial members of the cult) who are employed by wealthy individuals in these towns are seen featuring (with the recommendations of the $O w u$ Cult functionaries) in the $O w u$ Oma celebration in a particular village. For instance, it has been a common phenomenon for $O w u$ dancers owned by the indigenes of Amiri to feature in the Owu Oma celebration in Awo-Omamma. This thus assists in promoting cooperation culturally between both towns.

The Owu-Ulo-Akwa dance usually takes place during memorial activities of a deceased $O w u$ head. Its celebration is usually in accordance with the decision of the kinsmen of the deceased to accord the dead the last funeral rites only reserved for late $O w u$ functionaries. Thus through a unique dance, the deceased is bid farewell to the spirit world in appreciation of his unique role in the cult during his living days. With this celebration, the deceased does not return in fury haunting his in-group and his living co-heads for neglect. Hence, the dance is regarded as a sort of last ritual communion held with the deceased. However, during the celebration of Owu-UloAkwa in Awo-Omamma, indigenes of Amiri are usually present at the celebration. This alongside the other varieties in turn encourages cultural cooperation and interaction between the members of the aforementioned towns.

There are ceremonies which are associated with the Owu festival in Awo-Omamma, and Amiri. These ceremonies in one way or the other encourage cultural cooperation and interaction between the indigenes of the aforementioned towns, and some of them include the Emume ceremony, the Ito nri ali ceremony, and the Arana-Umu ceremony.

The Emume ceremony signifies the impending $O w u$ festival. It commences with the beating of the Ekwe Emume (a traditional cum ancestral drum)- a responsibility which lies with Umuezeali, and Umuocheta villages (the head villages of Awo-Omamma, and Amiri towns respectively). In Umuocheta village of Amiri, the drum is beaten by Umudiro kindred. The emume ceremony ushers in the rituals of the season which are associated with farming and annual festivals like the $O w u$ festival. None of the aforementioned activities will take place without first of all conducting the emume ceremony. Violating this custom is regarded as desecration of tradition which can attract the anger of the gods. When this happens, remedial measures (aimed at averting the fury of the gods) are sought for through atonement. However, when the ekwe emume has been beaten in either of both towns, the other town is notified through an emissary- a task which lies with the head villages. For instance, when Umuocheta village beats the ekwe emume, an emissary is sent to Umuezeali village to notify the people of the recent development, and vice versa. This promotes cultural cooperation.

Ito nri ali ceremony is celebrated by giving food to one's ancestors. The ceremony validates the observations of Victor Uchendu that the Igbo conceived their ancestors as the invisible segment of their lineage [26]. Similarly, the ceremony equally validates the views of F. Arinze (quoted in Patrick C. Obinabu) which holds that "...the Igbo family is not made up only of those who are still living in the flesh. The unseen ancestors are part of the family..." [27]. With this, different kinds of foods are provided and offered in sacrifice. At the end of the sacrifice, offerings are consumed communally. The ceremony usually affords the heads of every household the opportunity to communicate with his ancestor(s) via the medium of the family shrine, as well as solicit for their presence in the $O w u$ festival. This practice is in connection with the traditional belief that death is only a transition to another existence, and contact with the dead brethren must be maintained by rituals.

Ito nri ali ceremony in Awo-Omamma and Amiri towns usually provides the pedestal for friendly cooperation and interaction between the members of both towns. During its celebration in Awo-Omamma, friends and in-laws from Amiri town are invited. The invitation is usually reciprocated during the celebration of the ceremony in Amiri town. On honouring the invitation, the invitees are treated with adequate hospitality by their hosts [28].

Ara-na-umu ceremony, on the other hand, is recognised as a traditional mothers' day. In the feast, daughters of every family return home with their progenies from wherever they are married so as to identify with their family. As T.C. Ngimah noted, the ceremony “...forms a ritual link in the chain of the $O w u$ festivals" [29]. It also provides the opportunity for reunion with their parents and maternal grand parents of all married 
daughters and their children, respectively, at a stated time of the year. In some cases, these daughters return with their husbands to partake in the feast. Through this, the ceremony establishes bonds between sons-in-law (some of who are the indigenes of Amiri town since intermarriage exists between the indigenes of Awo-Omamma, and Amiri) and their wives' families. Thus, ara-na-umu ceremony contributes its quota in fostering friendly cultural cooperation and interaction between the towns of Awo-Omamma, and Amiri.

\section{Okorosha festival in Awo-Omamma-Amiri Relations}

The Okorosha is an institutionalized cult which operates within well-defined norms. The cult coordinates the Okorosha festival. As a masquerade festival, the Okorosha festival could be described as a ceremony of masked performers whose activities constitute of significant religious and social meaning in AwoOmamma, and Amiri towns.

The Okorosha festival is usually conducted within the $O w u$ festive period. According to Kelechi C. Ubaku, the festival "...indicates the coming to an end of the $O w u$ festive period, and its end equally marks the end of the aforementioned festive period. In addition, the celebration of this festival equally signifies the impending new yam festival" [30]. During this period, the masquerades operate freely in both towns. For instance, the Okorosha masquerades from Awo-Omamma operate freely in Amiri, and vice versa, during the celebration of masquerade (Okorosha) festival. This to a great extent promotes cultural cooperation and interaction between both towns.

The Okorosha masquerades, during the festival, perform functions such as maintaining law and order, in Awo-Omamma, and Amiri towns. They possess great influence on children with deviant tendencies having been used by parents to compel these children (who fear these masquerades) to show some acceptable behaviours. In addition, the Okorosha masquerades have their form of language which is hard to understand by children, the newly initiated members of the Okorosha Cult, and the uninitiated- the ordinary members of the towns who are not initiated into the cult. T.C. Ngimah provided an example of the language of the Okorosha masquerades. In his words,

...women are generally called aliga n'otu, which means that women are the same everywhere; water or rain is called ogba gere gere-oozer; money is called obe yoro yoro...; the shield which they use is called ekete ogu...; while sucking babies are addressed as ekulu (also pronounced ekuru) obielo, that is gladdeners of the heart [31].

\section{New Yam festival in Awo-Omamma-Amiri Relations}

Similar to most towns in Igbo land, the new yam festival is annually celebrated in Awo-Omamma, and Amiri towns. The festival is usually celebrated after the $O w u$ festive season in mid-August. Indigenously, it is known as emume iri nji ofuru.

The new yam festival in the aforementioned towns, according to Kelechi C. Ubaku,

...marks the beginning of the first harvest and the eating of fresh yams to

include water yam (Dioscorea Alata) which is indigenously known as nji ashara/nji nkiti, yellow yam (Dioscorea Cayenesis) which is called nji ogbagada, and white yam (Dioscorea Rotundata) also called nji agah/nji okomocha, in different homesteads [32].

The key moment in the festival, according to him, is the period of "...cooking and consumption of boiled yams with chicken pepper soup... called nji mmiri awa" [33].

The new yam festival in Awo-Omamma, and Amiri affords the indigenes of these towns the opportunity to interact with one another- a development usually encouraged by giving out invitations to in-laws, friends, well wishers, and chieftaincy title holders in the other town when one is celebrating her new yam festival. Invariably, therefore, the indigenes of Awo-Omamma are invited by the indigenes of Amiri during the latter's new yam celebration- an act which is usually reciprocated by the former during their new yam celebration. Through this means, the festival assists in fostering cultural cooperation and interaction among the aforementioned groups.

Awo-Omamma, and Amiri towns do not celebrate the new yam festival on the nkwo market day- the first market day on the Igbo cultural calendar. This is as a result of the abhorrence of this day as a day of merriments. Only the Njaba deity celebrates the new yam festival on this day. Consequently, items such as tubers of yams, fowls, and kola nuts, are offered to the Njaba deity by the pagans of these towns, at the bank of the Njaba River, or at the intermediary shrines of the Njaba deity stationed at different points in the towns. This traditional exercise known as Iwara Njaba Nji (in Awo-Omamma) or Iwara Nkwo Amiri Nji (in Amiri) must be carried out prior to the proper celebration of the new yam festival which can be conducted either on the eke, orie, or afor market days- other market days on the Igbo cultural calendar alongside nkwo market day. 


\section{Conclusion}

From the foregoing, it is evident that cultural festivals in Igbo land can provide the pedestal for unity and solidarity among members of different towns in relating with one another. The periods of these festivals afford the indigenes of these towns the opportunity to return home from their bases so as to imbibe and learn the lessons of kinship and cultural powwow. They make for town-oriented life, as well as affording relations and friends the opportunity to live in conscious dependence on one another. In addition, they give the celebrants a sense of unity, and provide them with a link to their past and a measure of hope for the future.

Thus, as examples of cultural festivals in Igbo land, the $O w u$, Okorosha, and new yam festivals have been providing the pedestal for cordial social and cultural relations between the indigenes of Awo-Omamma and Amiri towns. Despite the recent Otunne problem whose nucleus was captured from the breach of political agreement between the members of the aforementioned towns, cultural festivals have continued to perpetuate friendliness in the post Nigerian-Biafran Civil War relations of Awo-Omamma, and Amiri.

\section{References}

[1]. J. Lai, Nigeria: Shadow of a Great Nation, (Lagos: Dubeo Press, 1995), p.8.

[2]. "Nigerian Population" available in http://www.tradingeconomics.com/nigeria/population (Accessed, 31 July, 2013).

[3]. J. Lai, Nigeria: Shadow of a Great Nation, (Lagos: Dubeo Press, 1995), p.8.

[4]. T.C. Ngimah, Modernization and Change in the Celebration of Owu Festival in Awo-Omamma, B.Sc Project, University of Nigeria, Nsukka, 1978, p.7.

[5]. K. C. Ubaku, Awo-Omamma-Amiri Relations, since 1970, Master Thesis, Nnamdi Azikiwe University, Awka, 2012 , p.2.

[6]. G. Ukwuegbu, in an interview held in his residence at Nchoko Village, Amiri, 2013.

[7]. C. Omeziri, in an interview held in his residence at Ubogwu Village, Awo-Omamma, 2012.

[8]. K.C. Ubaku, Awo-Omamma - Amiri Relations, since 1970, pp.117-122.

[9]. K.C. Ubaku, Awo-Omamma-Amiri Relations, since 1970, p.51.

[10]. H. Ojinnaka, in an interview held in his residence, at Ubachima Village, Awo-Omamma, 2012.

[11]. Saturday Mirror, Vol. 02 No. 14, 17 March, 2012, p.35.

[12]. D. Getz, The Nature and Scope of Festival Studies, International Journal of Event Management Research, Vol. 5(1), 2010, 1-47, p.2. Also Available in www.Ijemr.org

[13]. "Collins Dictionary", retrieved from http://www.collinsdictionary.com on 08 August, 2013.

[14]. G.T. Basden, Niger Ibos, (London: Frank Cass \& Co. Ltd, 1966), p.71.

[15]. G.T. Basden, Niger Ibos, p.58.

[16]. A. Falassi, (Ed) Time Out of Time: Essays on the Festival, (Albuquerque: University of Mexico Press, 1987$)$, p.2.

[17]. D. Getz, Event Management and Event Tourism 2 ${ }^{\text {nd }}$. ed., (New York: Cognizant, 2005), p.21.

[18]. J. Pieper, In Tune with the World: A Theory of Festivity, (New York: Harcourt, 1965).

[19]. V. Okeke, The Owu Cultural Festival, in V.O. Okeke and F.N. Nnadi (Eds), Awo-Omamma: A Land of Beauty, (Owerri: Kemano Prints and Publishers, 2010) 119-127, pp.119-120.

[20]. T.C. Ngimah, Modernization and Change in the Celebration of Owu Festival in Awo-Omamma, pp.25-28. See also K.C. Ubaku, Awo-Omamma - Amiri Relations, since 1970, pp.70-71.

[21]. J.C. Nwadike and J.O. Nwoke, The Oghu Cultural Festival of Okwudor People: An Aspect of Igbo Tradition and Culture, Mmiri Imo: Journal of History and International Studies, Vol. 1 (1), 2012, 1-15, p.2.

[22]. T.C. Ngimah, Modernization and Change in the Celebration of Owu Festival in Awo-Omamma, p.29.

[23]. T.C. Ngimah, Modernization and Change in the Celebration of Owu Festival in Awo-Omamma, pp.31-35.

[24]. T.C. Ngimah, Modernization and Change in the Celebration of Owu Festival in Awo-Omamma, pp.40-41.

[25]. G. Ukwuegbu, in an interview held in his residence at Nchoko Village, Amiri, 2012.

[26]. V. Uchendu, The Igbo of Southeast Nigeria, (Ibadan: Nestea, 1965).

[27]. F. Arinze quoted in P.C. Obinabu, The Osu Caste System: A Critical Challenge to the Discipleship of the Church in Igbo land, Examined in the Light of St. Luke's Gospel, (Orlu: Chimavin Productions, 2004), p.18.

[28]. G. Ukwuegbu, 2012.

[29]. T.C. Ngimah, Modernization and Change in the Celebration of Owu Festival in Awo-Omamma, p.70.

[30]. K.C. Ubaku, Awo-Omamma-Amiri Relations, since 1970, p.81.

[31]. T.C. Ngimah, Modernization and Change in the Celebration of Owu Festival in Awo-Omamma, p.81.

[32]. K.C. Ubaku, Awo-Omamma - Amiri Relations, since 1970, p.83.

[33]. K.C. Ubaku, Awo-Omamma - Amiri Relations, since 1970, p.83. 


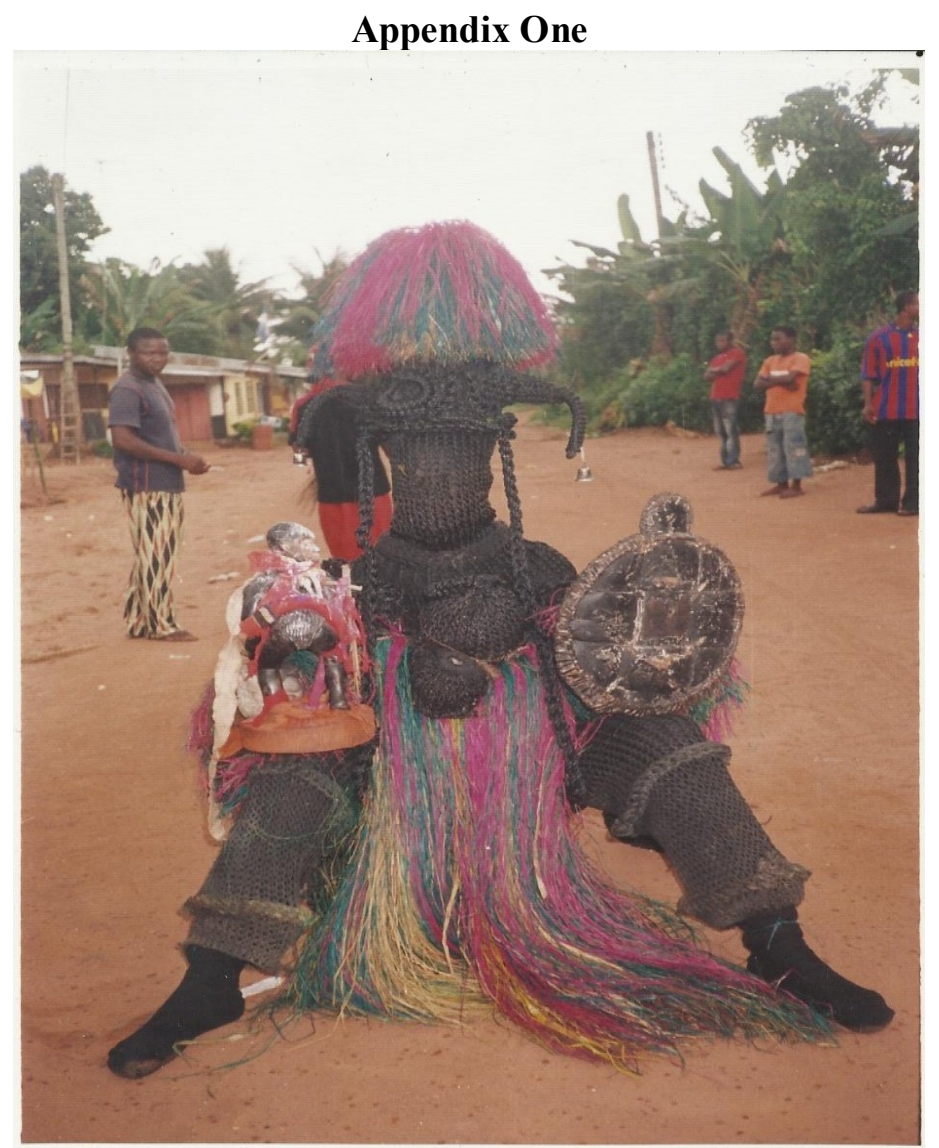

A picture of Okorosha masquerade in Awo-Omamma



A picture of $O w u$ dancers in Owu abuba costume in Awo-Omamma 


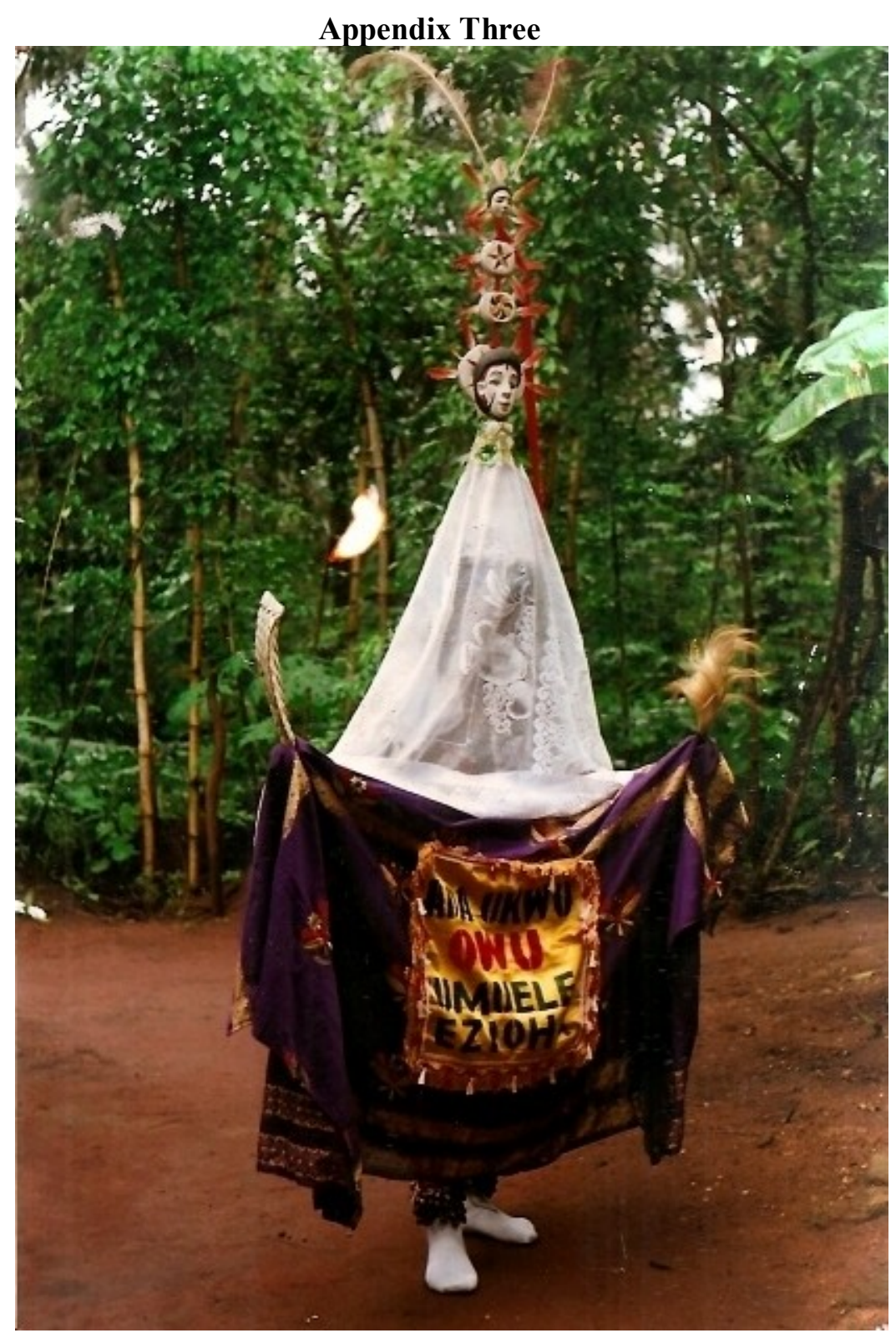

A picture of an Owu dancer in Owu Oma costume in Awo-Omamma 